$$
\begin{gathered}
\text { Text to accompany: } \\
\text { Open-File Report 79-1113 }
\end{gathered}
$$

1979

COAL RESOURCE OCCURRENCE MAPS AND

COAL DEVELOPMENT POTENTIAL MAPS OF THE

NORTHEAST QUARTER OF THE AZTEC 15-MINUTE QUADRANGLE, SAN JUAN COUNTY, NEW MEXICO

[Report includes 11 plates]

by

Dames \& Moore

This report has not been edited for conformity with U.S. Geological Survey editorial standards or stratigraphic nomenclature. 
Introduction
Purpose
Location
Accessibility
Physiography
Climate
Land status
General geology
Previous work
Geologic history
Stratigraphy
Structure

$\begin{array}{ll}\text { Coal geology } & 7\end{array}$

Fruitland 3 coal bed 10

Chemical analyses of the Fruitland 3 coal bed 10

$\begin{array}{ll}\text { Fruitland coal zone } & 10\end{array}$

Chemical analyses of the Fruitland zone coal beds 11

$\begin{array}{ll}\text { Coal resources } & 11\end{array}$

$\begin{array}{ll}\text { Coal development potential } & 13\end{array}$

Development potential for surface mining methods 13

Development potential for subsurface mining methods 13

$\begin{array}{ll}\text { References } & 16\end{array}$ 


\section{CONTENTS}

\section{PLATES}

Coal resource occurrence maps:

Plate 1. Coal data map

2. Boundary and coal data map

3. Coal data sheet

4. Isopach map of the Fruitland 3 coal bed

5. Structure contour map of the Fruitland 3 coal bed

6. Isopach map of overburden of the Fruitland 3 coal bed

7. Areal distribution and identified resources of the Fruitland 3 coal bed

8. Isopach map of the total coal of the Fruitland coal zone

9. Structure contour map of the Fruitland coal zone

10. Isopach map of overburden and interburden of the Fruitland coal zone

Coa1 development potential maps:

11. Subsurface mining methods

\section{TABLES}

Table 1. Analyses of coal samples from the Fruitland Formation

2. Coal resource data for underground mining methods for Federal coal lands (in short tons) in the northeast quarter of the Aztec 15-minute quadrangle, San Juan County, New Mexico 


\section{INTRODUCTION}

\section{Purpose}

This text is to be used in conjunction with the Coal Resource Occurrence (CRO) Maps and Coal Development Potential (CDP) Map of the northeast quarter of the Aztez 15-minute quadrangle, San Juan County, New Mexico. These maps were compiled to provide a systematic coal resource inventory of Federal coal lands in Known Recoverable Coal Resource Areas (KRCRA's) of the western United States. The work was performed under contract with the Conservation Division of the U.S. Geological Survey (Contract No. 14-080001-17172)

The resource information gathered in this program is in response to the Federal Coal Leasing Amendments Act of 1976 and is a part of the U.S. Geological Survey's coal program. The information provides basic data on coal resources for land-use planning purposes by the Bureau of Land Management, state and local governments, and the public.

\section{Location}

. The northeast quarter of the Aztec 15-minute quadrangle is located in northeastern San Juan County, New Mexico, directly south of the Colorado border. The area is approximately 25 miles $(40 \mathrm{~km})$ northeast of Farmington, New Mexico. 
Accessibility

The northeast quarter of the Aztec 15-minute quadrangle is accessible by New Mexico State Route 550 which extends across the northwestern corner of the area. Light-duty roads provide access to other parts of the quadrangle. The Atchison, Topeka, and Santa Fe Railway operates a route approximately 115 miles $(185 \mathrm{~km}$ ) south of the area at Gallup, New Mexico.

\section{Physiography}

This quadrangle is in the northwestern portion of the Central Basin area (Kelley, 1950) of the structural depression known as the San Juan Basin. Elevations range from $5,899 \mathrm{ft}(1,798 \mathrm{~m})$ in the Animas River Valley to $7,216 \mathrm{ft}(2,199 \mathrm{~m})$ at the top of Timbered Cone in the center of the area. The Animas River flows southwest across the northwestern corner of the quadrangle and is bounded by steep, terraced canyon walls on its east side. The remainder of the area has been carved by streams into steep-walled canyons which drain into the Animas River to the west or the San Juan River to the south.

\section{Climate}

The climate of the San Juan Basin is arid to semi-arid. Annual precipitation is usually less than about 10 inches $(25 \mathrm{~cm})$ with slight variations across the basin due to elevational differences. Rainfall is rare in the early summer and winter; most precipitation is received in July and 
August as intense afternoon thundershowers. Annual temperatures range from below $0^{\circ} \mathrm{F}\left(-18^{\circ} \mathrm{C}\right)$ to over $100^{\circ} \mathrm{F}\left(38^{\circ} \mathrm{C}\right)$ in the basin. Snowfall may occur from November to April.

\title{
Land Status
}

\begin{abstract}
Approximately 3 percent of the quadrangle is in the northern part of the San Juan Basin Known Recoverable Coal Resource Area. The Federal Government owns the coal rights for all of the KRCRA land within the quadrangle as shown on Plate 2 of the Coal Resource 0ccurrence Maps. No Federal coal leases occur in the quadrangle.
\end{abstract}

\section{GENERAL GEOLOGY}

\section{Previous Work}

Reeside (1924) mapped the surficial geology of the area on a scale of $1: 250,000$ as part of a study of the Upper Cretaceous and Tertiary formations of the San Juan Basin. More recently, Fassett and Hinds (1971) made subsurface interpretations of Fruitland Formation coal occurrences in the quadrangle area as part of a larger San Juan Basin coal study.

\section{Geologic History}

The San Juan Basin, an area of classic transgressive and regressive sedimentation, provided the ideal environment for formation of coals during 
Late Cretaceous time. At that time a shallow epeiric sea, which trended northwest-southeast, was northeast of the basin. The sea transgressed southwesterly into the basin area and regressed northeasterly numerous times; consequent1y, sediments from varying environments were deposited across the basin. Noncarbonaceous terrestrial deposition predominated during Paleocene and Eocene time.

Depositional evidence of the final retreat of the Late Cretaceous sea is the nearshore regressive Pictured Cliffs Sandstone. Southwest (shoreward) of the beach deposits, swamps, which were dissected by streams, accumulated organic matter which later became coals of the Fruitland Formation. Deposition of organic material was influenced by the strandline as shown by both the continuity of the coal beds parallel to the northwest-southeast strandine and their discontinuity perpendicular to it to the northeast. The less continuous Fruitland coals appear to be noncorrelative, but are stratigraphically equivalent in terms of their relative position within the Fruitland Formation.

The brackish-water swamp environment of the Fruitland moved farther to the northeast as the regression continued in that direction. Terrestrial freshwater sediments then covered the quadrangle area as indicated by the lacustrine, channel, and floodplain deposits of the Kirtland Shale. This sequence of events is evidenced by both an upward decrease in occurrence and thickness of Fruitland coals and a gradational change to noncarbonaceous deposits of the Kirtland. Continuous deposition during Late Cretaceous time ended with the Kirtland. The sea then retreated beyond the limits of the quadrangle area, and modern basin structure began to develop. An erosional unconformity developed in a relatively short time as part of the Cretaceous Kirtland Shale was removed. 
Terrestrial deposition resumed in the Paleocene as represented by the Ojo Alamo Sandstone and the overlying Nacimiento Formation. Alluvial plain and floodplain deposits of the Ojo Alamo were followed by the thick, lithologically varied deposits of the Nacimiento during continuous nonmarine deposition. The Nacimiento was later exposed to erosion.

The Eocene San Jose Formation was subsequently deposited over the Nacimiento erosional surface, reflecting various nonmarine environments which developed across the basin. Deposition and structural deformation of the basin then ceased, and the warped strata of the San Juan Basin have been exposed to erosional processes to the present time.

\section{Stratigraphy}

The formations studied in this quadrangle range from Late Cretaceous to Eocene in age. They are, in order from oldest to youngest: the Pictured Cliffs Sandstone, Fruitland Formation, Kirtland Shale, Ojo Alamo Sandstone, Nacimiento Formation, and San Jose Formation. A composite columnar section on CRO Plate 3 illustrates the stratigraphic relationships of these formations and is accompanied by 1ithologic descriptions of the individual formations.

The Pictured Cliffs Sandstone averages $190 \mathrm{ft}(58 \mathrm{~m})$ thick in this area. Because this unit is present throughout most of the San Juan Basin and easily recognized on geophysical logs, the top of the Pictured Cliffs Sandstone was picked as the datum (CRO Plate 3) for Fruitland coal correlations. The formation consists of a light gray, calcareous, argillaceous sandstone with interbedded gray, micaceous, fissle shale. Intertonguing with 
the overlying Fruitland Formation occurs throughout the entire basin and, consequent1y, minor Fruitland coal beds are commonly present in the upper portion of the Pictured Cliffs Sandstone.

The major coal-bearing unit in the quadrangle is the Fruitland Formation. Wide variations in reported thickness of the Fruitland are common due to an indistinct upper contact with the Kirtland Shale, but the average is about $420 \mathrm{ft}(128 \mathrm{~m})$ in this quadrangle. Many authors have utilized various criteria for establishing the upper contact, but, in general, for this study the uppermost coal was chosen (after Fassett and Hinds, 1971). The formation consists primarily of gray, carbonaceous shale with plant fossils and siderite nodules, interbedded light gray, calcareous sandstone, interbedded light gray siltstone with plant fossils, and lenticular coal beds.

The Upper Cretaceous Kirtland Shale conformably overlies the Fruitland Formation and averages $795 \mathrm{ft}(242 \mathrm{~m})$ in thickness in this area. It consists predominantly of freshwater, gray to gray-green siltstone with plant fossils, and buff to light gray-green, slightly calcareous sandstone. The formation has previously been divided into several members by various authors; however, for the purposes of this report it was not necessary to distinguish between the individual members.

The Paleocene 0jo Alamo Sandstone unconformably overlies the Kirtland Shale. It is an average of $125 \mathrm{ft}(38 \mathrm{~m})$ of white to buff, coarsegrained to conglomeratic sandstone with angular grains and interbedded gray shale.

Approximately $1,145 \mathrm{ft}(349 \mathrm{~m})$ of the Paleocene Nacimiento Formation overlie the 0 jo Alamo Sandstone. These rocks are exposed exclu- 
sively along the western edge of the quadrangle where they consist of gray to gray-green shale, white, fine- to coarse-grained, locally conglomeratic sandstone with angular grains, and interbedded gray siltstone.

The San Jose Formation of Eocene age unconformably overlies the Nacimiento Formation and is exposed throughout the quadrangle, with the exception of the western edge. It is predominantly white to cream to light gray, locally conglomeratic, slightly calcareous sandstone, interbedded gray-green shale, and interbedded tan to gray, micaceous siltstone.

Structure

The northeast quarter of the Aztec 15-minute quadrangle is located in the Central Basin area (Kelley, 1950) of the major structural depression known as the San Juan Basin. The axis of the basin extends east-west through the center of the quadrangle area and trends in an arcuate pattern across the northern portion of the Central Basin area (Baltz, 1967). Reeside (1924) stated that the rocks in the area are "nearly horizontal".

COAL GEOLOGY

Three coal beds (Fruitland 1, Fruitland 2, Fruitland 3) and a coal zone (Fruitland) were identified in the subsurface of this quadrangle (CRO Plate 1). The Fruitland 1 (Fr 1) coal bed is defined by the authors as the lowermost coal of the Fruitland Formation; it is generally directly above the Pictured Cliffs Sandstone. The Fruitland 2 ( $F r 2$ ) coal bed is above the Fruitland 1; they are separated by a rock interval averaging $97.5 \mathrm{ft}$ (30 m); 
the Fruitland 3 (Fr 3 ) coal bed is above the Fruitland 2 separated by a rock interval averaging $60 \mathrm{ft}(18.3 \mathrm{~m})$. Within this quadrangle the Fruitland 1 and Fruitland 2 coal beds are less than reserve base thickness ( $5 \mathrm{ft}$ [ $1.5 \mathrm{~m}]$ ) in areas with less than $3,000 \mathrm{ft}(914 \mathrm{~m})$ of overburden (the study limit). Therefore, derivative maps were not constructed.

Although these coal beds have been correlated, and in some cases mapped as consistent horizons, they may actually be several different coal beds that are lithostratigraphically equivalent but not laterally continuous. The remaining coals in the upper portion of the Fruitland Formation have been designated as the Fruitland coal zone (Fr zone) which extends from the top of the Fruitland Formation to the base of the lowermost coal designated on CRO Plate 3 as a Fruitland zone coal bed.

Fruitland Formation coals in the northern part of the San Juan Basin are considered high volatile A bituminous in rank. The rank has been determined on a moist, mineral-matter-free basis with calorific values averaging 15,412 Btu's per pound $(35,848 \mathrm{kj} / \mathrm{kg}$ ) (Amer. Soc. for Testing and Materials, 1977). The coal is hard, brittle, and black with a bright luster. The coal readily slakes with exposure; however, it stocks fairly well when protected. The "as received" analyses indicate moisture content varying from 1.3 to 2.3 percent, ash content ranging from 11.0 to 29.2 percent, sulfur content less than one percent, and heating values on the order of 10,690 to $13,350 \mathrm{Btu}$ 's per pound $(24,865-31,052 \mathrm{kj} / \mathrm{kg})$. Analyses of several Fruitland Formation coals are given in Table 1 (Bauer and Reeside, 1921; Fassett and Hinds, 1971). 


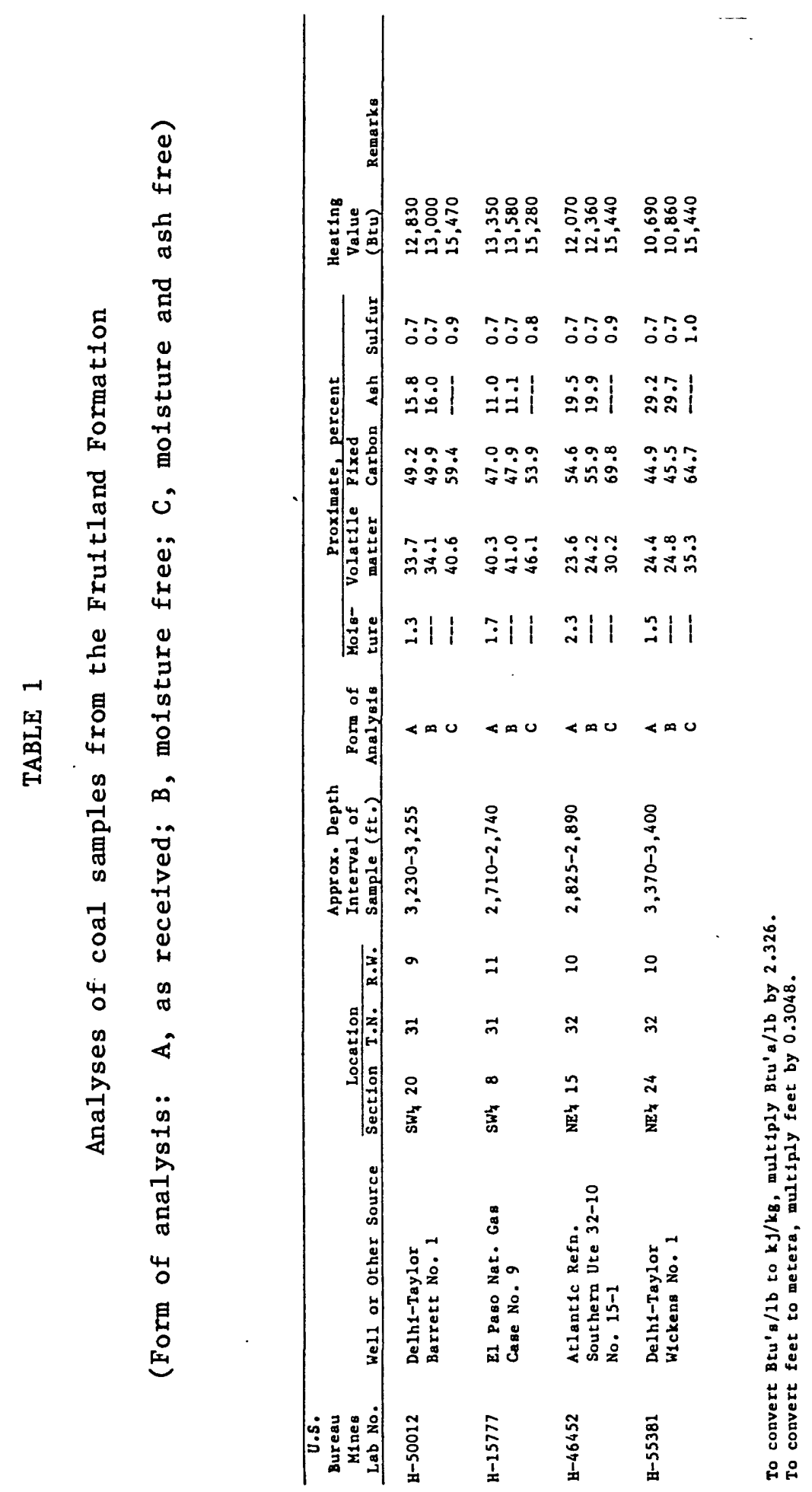


The Fruitland 3 coal bed has been mapped only in areas with less than $3,000 \mathrm{ft}(914 \mathrm{~m})$ of overburden (the study limit). The coal bed dips less than $1^{\circ}$ to the northeast as shown by the structure contour map (CRO Plate 5). As a result of topography and dip, the overburden (CRO Plate 6) thickness varies from less than $2,600 \mathrm{ft}(792 \mathrm{~m})$ in Ditch Canyon in the west to more than $3,000 \mathrm{ft}(914 \mathrm{~m})$ over much of the quadrangle. The coal bed has a thickness of more than $15 \mathrm{ft}(4.6 \mathrm{~m})$ in the southwest part of the map as illustrated by the isopach map (CRO Plate 4). The thickness decreases in all directions, and the coal is absent from areas in the west-central and southwest.

Chemical Analyses of the Fruitland 3 Coal Bed - Analyses of several coals of the Fruitland Formation from this quadrangle and the surrounding area are given in Table 1 (Fassett and Hinds, 1971).

\section{Fruitland Coal Zone}

The Fruitland coal zone extends from the top of the Fruitland Formation to the base of the lowermost coal designated on CRO Plate 3 as a Fruitland zone coal bed. The coal zone has been mapped only in areas with less than $3,000 \mathrm{ft}(914 \mathrm{~m})$ of overburden (the study limit). The structure contour map (CRO Plate 9) of the coal zone was drawn using the top of the Fruitland Formation. It shows that the coal zone dips less than $1^{\circ}$ to the northeast and indicates a minor structural depression in the southwest. As a result of topography and dip, overburden (CRO Plate 10) thickness varies 
from less than $2,500 \mathrm{ft}(762 \mathrm{~m})$ in the vicinity of Ditch Canyon to greater than 3,000 ft $(914 \mathrm{~m})$. Also shown on CRO Plate 10 is the total amount of interburden which is the noncoal-bearing portion of the coal zone. The thickness varies from zero to greater than $250 \mathrm{ft}(76 \mathrm{~m})$, reflecting the stratigraphic spread of the coals in the formation. The isopach map (CRO Plate 8) shows the total thickness of the coals within the zone. The maximum accumulated thickness is greater than $15 \mathrm{ft}(4.6 \mathrm{~m})$ and occurs in the south. In general, the coal thickness decreases from this area, and the coal is absent in the northwest part of the map.

$$
\text { Chemical Analyses of the Fruitland Zone Coal Beds - Analyses of }
$$

several coals of the Fruitland Formation from this quadrangle and the surrounding area are given in Table 1 (Fassett and Hinds, 1971).

\section{COAL RESOURCES}

Coal resource data from oil and gas wells and pertinent publications were utilized in the construction of isopach and structure contour maps for this quadrangle. All of the coals studied in the northeast quarter of the Aztec 15-minute quadrangle occur more than $200 \mathrm{ft}(61 \mathrm{~m})$ below the ground surface and, thus, have no outcrop or surface development potential.

The U.S. Geological Survey designated the Fruitland 3 coal bed for the determination of coal resources in this quadrangle. Coals of the Fruitland 1, Fruitland 2, and Fruitland zone were not evaluated because the thickness of the coal beds is generally less than the reserve base thickness (5 ft $[1.5 \mathrm{~m}])$. In addition, these coals are irregular, noncorrelative, and limited in areal extent. 
For Reserve Base and Reserve calculations, the Fruitland 3 coal bed was areally divided into measured, indicated, and inferred resource categories (CRO Plate 7) according to criteria established in U.S. Geological Survey Bulletin 1450-B. Data for calculation of Reserve Base and Reserves for each category were obtained from the coal isopach (CRO Plate 4) and areal distribution maps (CRO Plate 7). The surface area of the isopached Fruitland 3 bed was measured by planimeter, for each category, in acres, then multiplied by the average isopached thickness of the coal bed and 1,800 short tons of coal per acre-foot $(13,239$ tons/hectare-meter), the conversion factor for bituminous coal. This yields the Reserve Base coal, in short tons, for the Fruitland 3 coal bed.

In order to calculate Reserves, a recovery factor of 50 percent was applied to the Reserve Base tonnages for underground coal. However, in areas of underground coal exceeding $12 \mathrm{ft}(3.7 \mathrm{~m})$ in thickness, the Reserves (mineable coal) were calculated on the basis of a maximum coal bed thickness of $12 \mathrm{ft}(3.7 \mathrm{~m})$, which represents the maximum economically mineable thickness for a single coal bed in this area by current underground mining technology. Reserve Base and Reserve values for measured, indicated, and inferred categories of coal for the Fruitland 3 coal bed are shown on CRO Plate 7 , and are rounded to the nearest hundredth of a million short tons. The total coal Reserve Base, by section, is shown on CRO Plate 2 and totals approximately 13.7 million short tons (12.4 million metric tons).

The coal development potential for the Fruitland 3 bed is calculated in a manner similar to the Reserve Base, from planimetered measurements, in acres, for areas of high, moderate, and low potential for 
subsurface mining methods. The northeast quarter of the Aztec 15-minute quadrangle has development potential for subsurface mining methods only (CDP P1ate 11).

COAL DEVELOPMENT POTENTIAL

Coal beds of $5 \mathrm{ft}(1.5 \mathrm{~m})$ or more in thickness which are overlain by 200 to $3,000 \mathrm{ft}(61-914 \mathrm{~m})$ of overburden are considered to have potential for underground mining, and are designated as having high, moderate, or low development potential according to the overburden thickness: 200 to $1,000 \mathrm{ft}$ $(61-305 \mathrm{~m})$, high; 1,000 to $2,000 \mathrm{ft}(306-610 \mathrm{~m})$, moderate; and 2,000 to 3,000 ft (610-914 m), 1ow. Table 2 summarizes the coal development potential, in short tons, for underground coal of the Fruitland 3 coal bed.

\section{Development Potential for Surface Mining Methods}

A11 coals studied in the northeast quarter of the Aztec 15-minute quadrangle occur more than $200 \mathrm{ft}(61 \mathrm{~m})$ below the ground surface and, thus, they have no coal development potential for surface mining methods.

Development Potential for Subsurface Mining Methods

Underground coal of the Fruitland 3 coal bed has low development potential in two-thirds of the KRCRA in the extreme southwest corner (CDP Plate 11). Coal bed thickness ranges from 5 to $15 \mathrm{ft}(1.5$ to $4.6 \mathrm{~m})$ (CRO Plate 4) and overburden varies from $2,800 \mathrm{ft}$ to $3,000 \mathrm{ft}(853-914 \mathrm{~m})$ thick 


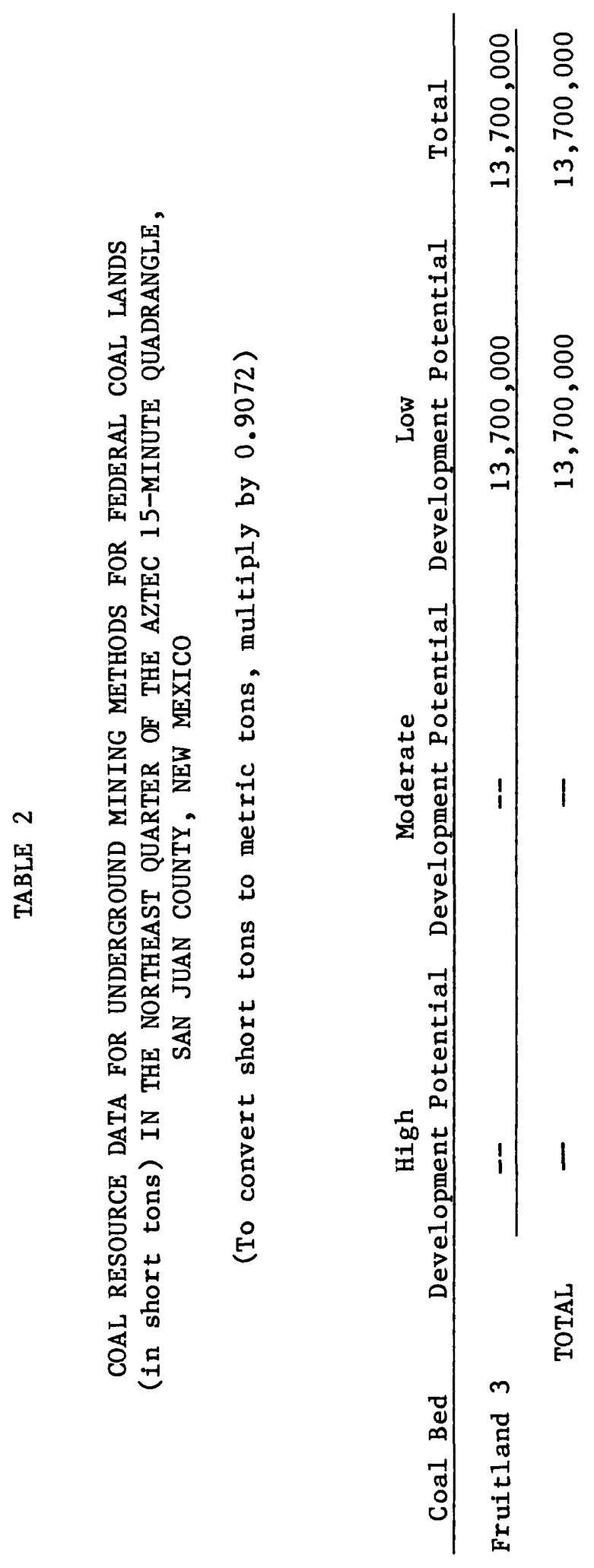


(CRO Plate 6). Some of the coal with low potential, located along the south border of the quadrangle, is the result of the Fruitland 4 bed in the adjacent quadrangle, the southeast quarter of the Aztec 15-minute quadrangle. The remaining area in the southwest has unknown potential where the Fruitland 3 coal bed is less than the reserve base thickness of $5 \mathrm{ft}(1.5 \mathrm{~m})$. 


\section{REFERENCES}

American Soc. for Testing and Materials, 1977, Gaseous fuels; coal and coke; atmospheric analysis, in Annual book of ASTM standards, part 26: p. 214-218.

Baltz, E.H., Jr., 1967, Stratigraphy and regional tectonic implications of part of Upper Cretaceous and Tertiary rocks, east-central San Juan Basin, New Mexico: U.S. Geol. Survey Prof. Paper 552, p. 12.

Bauer, C.M., and Reeside, J.B., Jr., 1921, Coal in the middle and eastern parts of San Juan County, New Mexico: U.S. Geol. Survey Bul1. 716-G, p. $177-178$.

E1 Paso Natural Gas Co., Well log library, Farmington, New Mexico.

Fassett, J.E., and Hinds, J.S., 1971, Geology and fuel resources of the Fruitland Formation and Kirtland Shale of the San Juan Basin, New Mexico and Colorado: U.S. Geol. Survey Prof. Paper 676, 76 p.

Kelley, V.C., 1950, Regional structure of the San Juan Basin in New Mexico Geol. Soc. Guidebook of the San Juan Basin, New Mexico and Colorado, 1st Field Conf., p. 102.

Reeside, J.B., Jr., 1924, Upper Cretaceous and Tertiary formations of the western part of the San Juan Basin of Colorado and New Mexico: U.S. Geol. Survey Prof. Paper 134, p. 1-70.

U.S. Bureau of Mines and U.S. Geological Survey, 1976, Coal resource classification system of the U.S. Bureau of Mines and U.S. Geological Survey: U.S. Geol. Survey Bull. 1450-B, 7 p.

U.S. Department of the Interior, 1950, Map of portion of San Juan County, New Mexico, and La Plata County, Colorado: U.S. Geol. Survey 011 and Gas Operations Map Roswel1 60, revised 1972, 1:31,680. 